\title{
Studies in laser safety of new high-output systems
}

\section{TEA CO 2 laser impacts}

\author{
Received 7th August 1972 \\ L. GOLDMAN*, E. YABLONOVITCH, N. BLOEMBERGEN†, \\ D. RICHFIELD*
}

The new TEA (transversely excited atmospheric pressure) $\mathrm{CO}_{2}$ laser can produce ionization of air. No information is as yet available of the effect of this new high-power output laser on man. Repeated impacts of $30 \mathrm{~mJ}$ pulses with $100 \mathrm{~kW}$, which produced ionization of air, caused non-specific superficial coagulation necrosis which healed promptly.

Impacts of high intensity laser beams on living tissue continue to be of great interest. ${ }^{1-3}$ The $\mathrm{CO}_{2}$ laser has been used with outputs of $300 \mathrm{~W}$ on skin, liver, bone and kidney of dogs. ${ }^{4}$ Powers of 85 to $100 \mathrm{~W}$ have been used in investigative laser surgery for man. A special type of high intensity $\mathrm{CO}_{2}$ laser is the TEA $\mathrm{CO}_{2}$ laser, a transversely excited atmospheric pressure $\mathrm{CO}_{2}$ laser. This is used extensively in research and industrial applications. This laser can produce ionization oi air. Smith and Gerger, ${ }^{5}$ with $200 \mathrm{~ns}$ pulses from a $\mathrm{TEA} \mathrm{CO}_{2}$ laser, determined that the minimum threshold intensity for atmospheric air was $3 \times 10^{9} \mathrm{~W} \mathrm{~cm}^{-2}$ for a spot diameter of $100 \mu \mathrm{m}$. It is necessary, then, to know of its reaction in human tissue. Initial exposures

* Laser Laboratory, University of Cincinnati Medical Center tGordon McKay Laboratory, Harvard University

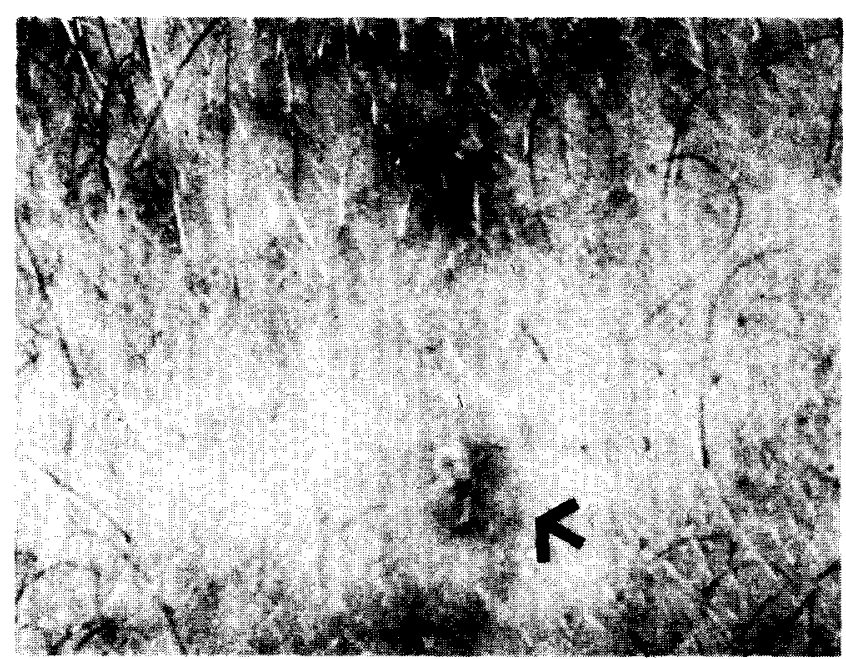

Fig.1 TEA CO $230 \mathrm{~mJ}$ pulse, $100 \mathrm{~kW}$ impact on torearın after 24 hours, showing reddened papule with superficial crusting of man to new laser systems are usually done on the skin of the flexor surface of the forearm.

In these experiments on the skin, the TEA laser had a helical electrode structure, operating in the lowest order of transverse gaussian mode. There were, also, several

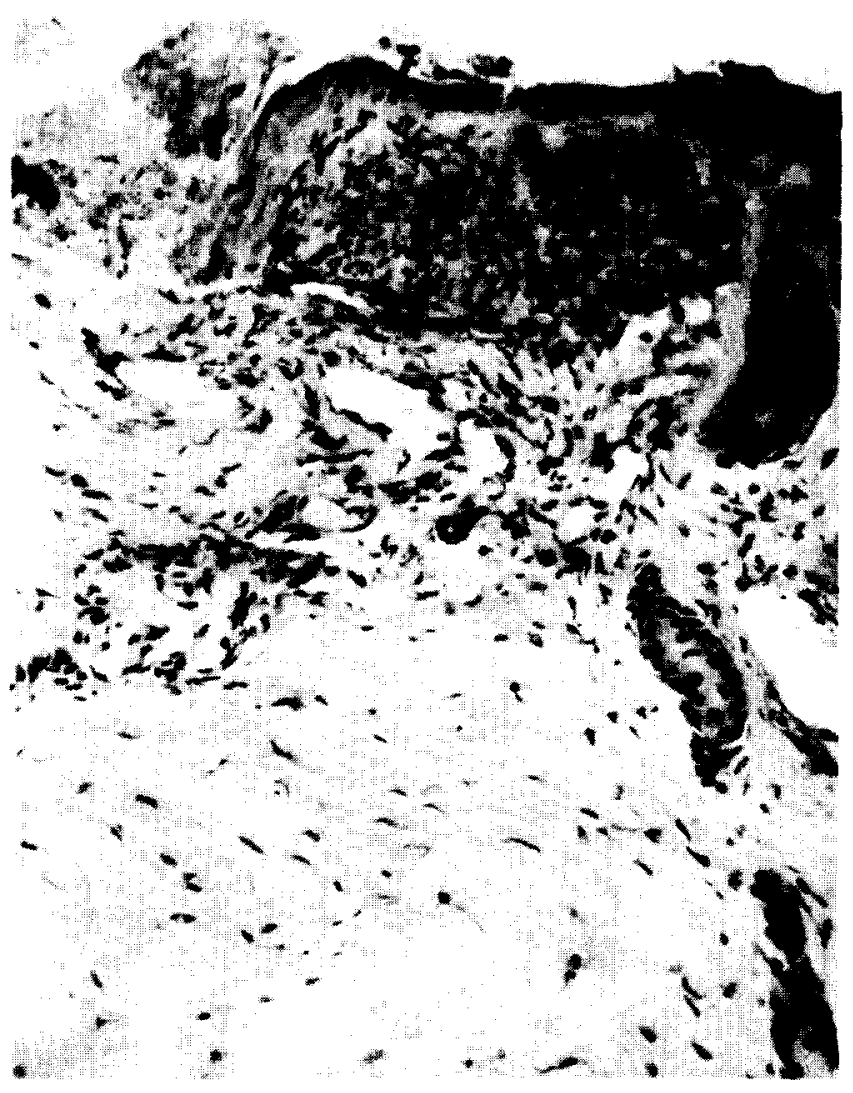

Fig. 2 Biopsy of TEA $\mathrm{CO}_{2}$ lesion showing superficial crusting, flattened epidermis, sharply circumscribed polymorphonuclear and lymphocytic infiltrate. Hematoxylin-eosin $\times 200$ 
longitudinal modes. In a previous report by Yablonovith ${ }^{6}$ the details of this laser and its pulses were described.

Pulses of $30 \mathrm{~mJ}(100 \mathrm{~kW})$ and with a diameter of approximately $100 \mu \mathrm{m}(0.5-0.25 \mathrm{~s}$ exposures) were given in four separate areas to the flexor surface of the left forearm of a Caucasian volunteer. Immediate prickling and burning were followed in several hours by erythema and in 24 hours by spreading ery thema, edema and superficial crusting (Fig.1). A biopsy of one of the 24-hour reactions was obtained. The other areas were left as controls.

Biopsy studies (Fig.2) showed a sharply limited zone of epidermal destruction with a sharply circumscribed zone of coagulation necrosis of the underlying dermis for a very shallow depth, and an accumulation of neutrophils and lymphocytes within the zone of coagulation. The impact zone and the inflammatory response was, then, sharply demarcated and relatively shallow. This non-specific inflammatory reaction does not differ from that observed from impacts of a $\mathrm{CO}_{2}$ laser on skin. ${ }^{2}$

The control areas healed within a week without any residual scarring. These healed areas were not excised. No scars could be observed over a period of six months.

Although this TEA $\mathrm{CO}_{2}$ laser produced ionization of air with a focused beam, the reactions in the skin of man at the focal point showed only a moderate degree of nonspecific thermal coagulation necrosis. These reactions were not similar in their initial changes or subsequent follow-up observations to those produced by $\mathrm{x}$-ray reactions.

These few and preliminary experiments on a single volunteer indicate that it is safe to conduct additional studies of this type on man's skin. Some additional studies which are needed are on comparative power densities of impacts of the $\mathrm{CO}_{2}$ and the TEA $\mathrm{CO}_{2}$ laser, the effects of chronic exposure, air pollution studies from material processing, and, finally, biomedical applications.

\section{References}

1 Goldman, L. Studies in laser safety of new high output systems. Applications of the laser (Chemical Publishing Co, to be published)

2 Goldman, L. Studies in laser safety of new high output systems, pico-second impacts, Optics and Laser Technology 5 (1973) 11

3 Goldman, L., Rockwell, R. J. Lasers in inedicine (Gordon \& Breach Science Publishers, New York, 1971)

4 Goldman, $\mathrm{L}$. Some parameters of the high output $\mathrm{CO}_{2}$ laser experimental surgery, Nature 228 (December) 1344-1345

5 Smith, D., Berger, P. United Aircraft Research Laboratories, Electro-Optical Systems Design 4 :5 (1972)

6 Yablonovitch, E. The optical dielectric strength of alkalihalide crystals obtained by laser induced breakdown. (to be published) 